\section{IJ§ER}

ISSN: 2149-5939
International Journal of Social Sciences and Education Research

Online, https://dergipark.org.tr/tr/pub/ijsser

Volume: 7(4), 2021

\title{
Teacher's roadblocks in the time of quarantine teaching*
}

\author{
Lovely C. Corcuera ${ }^{1}$ and Abel V. Alvarez, Jr. ${ }^{2}$ \\ ${ }^{1}$ Far Eastern University, Manila, Philippines, e-mail:lcorcuera@feu.edu.ph,ORCID: https://orcid.org/0000-0002-9597-7783 \\ ${ }^{2}$ Far Eastern University, Manila, Philippines, e-mail:aalvarez@feu.edu.ph,ORCID: https://orcid.org/0000-0002-2319-6881
}

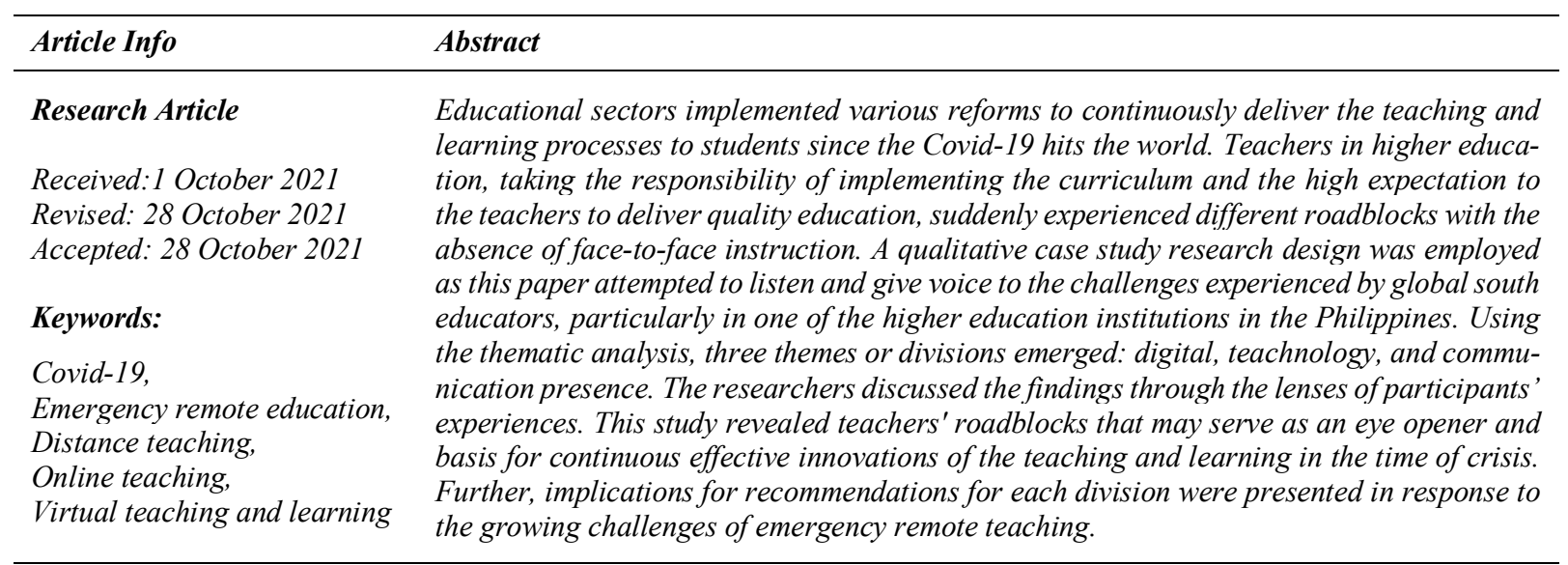

\section{Introduction}

As the Philippines is considered a developing country, a closer look at its educational system is needed to improve its quality. Various reforms and changes that aim to enhance its quality were done over the years. One of these is the implementation of the K-12 basic education program. However, these reforms, guidelines, and policies cannot just give sufficient and applicable data to continuously practice the quality in education since the contagious disease, Covid-19, hits the Philippines. As of September 2021, there were more than two million cases identified in the Philippines, which resulted to the closure of schools for the meantime. However, the Philippines is used to face-to-face mode of instruction. Further, the exploration of educational technology is still raw (e.g., Asio \& Bayucca, 2020; Tomaro \& Mutiarin, 2018, Toquero, 2020). Since Covid-19 continuously disrupts the normal functioning of the schools, the Higher Education Institutions (HEIs) introduced different modes of instruction for continuous teaching and learning during emergency remote education.

Emergency remote education seems to be the accurate term to define what is happening during this time of public health emergency (Bozkurt \& Sharma, 2020; and Bozkurt et al., 2020; Hodges, Moore, Lockee, Trust, \& Bond, 2020). HEIs implemented different measures that adhere to government directives to prevent the spread of the disease. These include execution of various teaching and learning alternatives (Joaquin \& Biana., 2020). However, one of the most affected here is the teachers in higher education. Teachers in higher education, taking the responsibility of implementing the curriculum and the high expectation to teachers to deliver quality education, suddenly experienced different roadblocks with the absence of face-to-face instruction. Studies such as this may help to discern profoundly and institutively their experiences regarding the change of teaching modalities (Koehler $\&$ Farmer, 2020). Further, the documentation of these different roadblocks may give an idea for educational leaders on proper actions to take in successfully delivering the emergency remote education to students.

\footnotetext{
*This study was presented at 5th International Congress on Action Research, Action Learning (ARAL 2021), De La Salle University, 20-22 May 2021. All responsibility belongs to the researchers. All parties were involved in the research of their own free will.
}

To cite this article: Corcuera, L.C. \& Alvarez, A.V. (2021). Teacher's roadblocks in the time of quarantine teaching. International Journal of Social Sciences and Education Research, 7 (4), 427-434. DOI: https://doi.org/10.24289/ijsser.1003162 


\section{Literature}

Even in pre-pandemic, teaching and learning continuously improve following the society's needs. The technology integration in education and utilization of different teaching modalities are innovative ways that have been practiced since then. The absence of face-to-face instruction due to Covid-19 intensified these innovations and developments. Researchers from various fields documented these to fit the new normal in education.

Numerous researches recorded the transition of face-to-face instruction to emergency remote education (e.g., Basilaia \& Kvavadze, 2020; Danjou, 2020; Gautam \& Gautam, 2020; Ho \& Tay, 2020; Naciri, Baba, Achbani, \& Kharbach., 2020; Quezada, Talbot, \& Quezada-Parker, 2020; Sintema, 2020; Yanus, Abubakar, \& Abudu, 2020). For instance, Naciri et al. (2020) explored the use of mobile as an alternative way of learning. Additionally, Basilaia and Kvavadze (2020) studied the use of the Google Meet Platform as an online form of education during the pandemic crisis. However, the successful implementation of these alternatives is not without its challenges.

There were several researchers emerged identifying these specific challenges, which focus on students' perspectives (e.g., Adnan \& Anwar, 2020; Coman, Tiru, Mesesan-Scmitz, Stanciu \& Bularca, 2020; Hussein Daoud, Alrabaiah, \& Badawi., 2020; Mishra, Gupta, \& Shree, 2020; Simamora, 2020; Tejedor, Cervi, Perez-Escoda, Tusa, \& Parola, 2020). For instance, Adnan and Anwar (2020) enumerated students' challenging experiences such as unavailability of the internet due to technical and financial issues, response time, absence of traditional classroom socialization, and lack of face-to-face interaction with teachers. Furthermore, Conman et al. (2020) also documented students' challenges: technical issues, teachers' lack of technical skills, improper teaching style, and lack of interaction with the teacher.

On the other hand, teachers were also continuously struggling to practice emergency remote education (Alea, Fabrea, Roldan, \& Farooqi, 2020; Santi, Gorghui \& Pribeanu, 2020). For instance, even though Iranian teachers had positive beliefs on technology in teaching English as a Foreign Language, they still encountered challenges (Khatoony \& Nezhadmehr, 2020). These include lack of appropriate materials, learner's lack of attention and demotivation, and lack of funding support from language institutions. Mishra et al. (2020) also noted other problems such as unstable internet connection, socio-economic status, power interruption, and lack of learning materials. However, there were limited researches regarding the teachers' roadblocks in higher education in the Philippine context.

HEIs utilized different teaching modalities to ensure that students still learn despite the prohibitions of faceto-face classes in the Philippines. For instance, Joaquin and Biana (2020) explored the alternative modes of instruction used by HEIs in the Philippines compared to Southeast Asian HEIs. However, when Asio and Bayucca (2021) analyzed the readiness on distance learning of 36 administrators, they found that administrators were not ready to implement distance learning and various challenges emerged from the study. The same problems were noted in the research conducted by Arinto way back in 2016. It is a clear indication that the idea of distance learning is still raw in the Philippines. Teachers, on the other hand, have been put into a unique position. The uncertainty of how to effectively implement the emergency remote education continuously gives roadblocks to the teachers.

Thus, there is a need to identify teachers' problems as they are in charge of the implementation of emergency remote education. Identifying their challenges offers an opportunity for both the students and teachers and even the school itself to further develop distance teaching and learning during and even after the emergency remote education. Furthermore, studies such as this may serve as an eye-opener and basis for policymakers to take appropriate action.

\section{Methodology}

\subsection{Research design}

Since the focus of this study is about examining the challenges experienced by educators in the time of emergency remote teaching, the researchers utilized qualitative case study research to understand in-depth the experiences and insights of the participants about their distance teaching journey (Merriam, 1998; Stake, 1995; Yin, 2009). At the same time, case study research provided the researchers an opportunity to examine a particular context of the educational institution. Further, it helped the researchers grasp and explore the shared meanings from the participants' experiences (Stake, 1995; Yin, 2009). Lastly, the researchers ensured involvement from data gathering to analyzing the data. Hence, the researchers served as a key instrument throughout the study (Creswell, 2005; Stake, 1995). 


\subsection{Participants and locale}

Ten participants were purposively selected following specific criteria. From 15 participants that were introduced by their cluster heads, only 10 confirmed their full participation. The others backed out in participating in this study due to personal reasons and time conflict. The selection criteria for the participants were: full-time higher education instructors, either male or female, handles business management courses, and engage in teaching remotely. Moreover, Merriam (1998) and Yin (2009) agreed that one of the characteristics of a case study is having a zone of focus. Therefore, this study was also bounded by a specific locale where it was conducted in one of the universities in Manila, Philippines. Table 1 shows the graphical representation of the demographic profile of the participants.

Table 1. Demographic profile of the participants

\begin{tabular}{ccc}
\hline Participant & Age & Years of teaching experience in higher education \\
\hline 1 & 47 & 27 \\
2 & 40 & 18 \\
3 & 27 & 3 \\
4 & 26 & 3 \\
5 & 37 & 12 \\
6 & 28 & 5 \\
7 & 43 & 15 \\
8 & 55 & 20 \\
9 & 35 & 13 \\
10 & 58 & 30 \\
\hline
\end{tabular}

\subsection{Data collection and data analysis}

Individual interviews were done according to the availability of the participants. Since face-to-face interaction was still prohibited due to the continuous surge of COVID-19 cases in the country, the researchers maximized technology-mediated communication tools such as MS Teams and Zoom. Moreover, the researchers explained the purpose and overview of this study to the participants to have a glimpse of the questions to be asked. Doing this served as establishing rapport to make the conversational interaction smooth (Patton, 1987).

Furthermore, the researchers utilized semi-structured interviews to gather authentic information from the participants (Merriam, 2002). In this way, it provided an opportunity to converse with the participants and learn from the challenges or roadblocks they experienced in teaching remotely. This process also helped the researchers to deepen the data through having an open-ended exchange of conversations (Esterberg, 2002; Kvale, 1996). The interviews lasted for about 15-20 minutes, and these were all audio-recorded to ensure the accuracy of the information they have shared (Merriam, 1998).

The researchers transcribed the interviews first. After which, researchers go through the process of reading and re-reading the transcripts to familiarize themselves with the data and make a preliminary analysis. Guided by the concepts of Braun and Clarke's (2013) thematic analysis, the data were initially coded by highlighting and descriptively coding the key statements of participants. Then, from these chunks of codes, the researchers reanalyzed and reorganized the small codes that emerged during the first cycle of the coding process to come up with subthemes or categories. These were refined and reconstruct to develop sets of themes. Further, these were peerchecked by two of the researchers' colleagues in the field to ensure the credibility of the results (Lincoln \& Guba, 1985).

\section{Findings}

This section provides findings of the study derived from higher education teachers' responses through thematic analysis. Interestingly, there were three themes or "division" revealed from this study: digital, teachnology, and communication presence. The theme "digital divide" entails the disparity of both the learners and the teachers to have quality and equitable access to internet connectivity. Despite having been in a digital society, the Covid-19 proved that nothing in this world is indispensable. Hence, this phenomenon served as a wake-up call that the digital divide exists. For instance, one of the significant challenges that $\mathrm{P} 3$ experienced in remote teaching was having a poor internet connection which resulted in being disconnected.

"Our internet connection is really bad. I mean, despite paying a huge amount of money for a cable internet, I am still experiencing poor internet connection, especially when I am having my online teaching. It makes me sick of the internet situation in our area." (P3) 
The same dilemma was also shared by his colleagues when asked about their teaching journey in the time of the pandemic crisis. To wit:

"It's about internet connection of students especially for those who are residing in the provinces. As much as I want to conduct synchronous lectures, I couldn't because of unreliable connectivity. I just miss having face-to-face class." (P4)

"There were instances when my students had sudden internet connectivity and technical issues while we are in the middle of class discussion. They notified me that they can no longer join the synchronous class because of issues on internet connection." (P5)

Interestingly, educators were not excluded from this problem of quality access to internet connectivity. Some also had bad limelight, even having availed higher internet bandwidth from service providers. P6 experienced having a sluggish virtual class which affected their virtual classroom productivity, thus, resulted in early class dismissal.

"From my experience, I am the only using our fiber internet, yet, I still experienced that there was a lag of presentation from my students. Some students also called my attention that they can no longer understand and see my slides." (P8)

Meanwhile, teachnology, as the term implies in this study, describes that division does not confine to the notion of the internet but also entails problems in teaching strategies and pedagogy of teachers in integrating technology in emergency remote education. For instance, P10 emphasized that in teaching management courses, one must be skilled in Microsoft excel and syntax. Moreover, P1 and P8 reminisced the time they had to figure out how to deliver their lectures interactively in an online setting which is new to them:

"The major obstacle that I have encountered in this particular subject was the translation of theories to reallife examples. It was quite a challenge for me wherein in the regular setting I can automatically link the discussion to a real-life activity." (P1)

P9 related his pedagogical challenges in technology integration, in which he had difficulty facilitating his students to engage and actively participate in virtual class discussions. Moreover, P8 also shared that:

"I do a lot of diagrams and links/arrows on a step by step process to solve a particular problem/case. However, when this was still done in face-to-face, I just used a pen and a blackboard to immediately show to my students the procedures in solving a problem.” (P8)

Likewise, some teachers' pedagogical problem as they continue to navigate emergency remote teaching was the teaching strategies on engaging students actively in virtual class. For instance, P9 shared that:

"One of the challenges is how to make the students as engaging and participative in the discussion. I have to make sure that the engagement is not monopolized by only one or two voices in the class. I had more than 50 students per class so facilitating a discussion to keep them engage was a challenged."

Lastly, the theme "communication presence" is perceived to be a challenge for some educators because of the transactional distance that exists between teachers and students. It also came to a point where P9 felt that her students had become demotivated due to the separation of time, space, and lack of physical exchange of conversations, insights, and ideas, she expressed:

"Since we don't meet in a face-to-face set-up, some students raised concerns about having been meeting limited to virtual setting. They felt being demotivated in their online class because they don't see and feel the real classroom setting, as they described. In fact, I sometimes experienced as well the lack of real conversations with my students because in today's online setting, they are more likely to be passive communicators. They are shy in expressing their insights, and even, sometimes, don't want to open their cameras during virtual class interaction." (P9)

At the same time, P8 agreed that students were becoming passive communicators. The virtual classroom became a roadblock for students to express their insights and feelings about the course they were into. To wit:

"From my experience, during the start of our online lecture, students don't immediately respond yes or no if they already see or hear you. Some students are also away from their devices when I called them for virtual recitation." 
This phenomenon had also been recalled by $\mathrm{P} 7$ where she shared that virtual communication somehow creates space for students and teachers since both parties were physically separated by time and space. There were instances that P7 was unaware of how her students reacted during their virtual discussions. P7 also believed that students' reaction is a vital component in continuous improvement in teaching and learning process. Thus, P7 agreed that "communication is an important aspect that teachers must go into regardless whether it is in virtual or physical classroom setting."

\section{Discussions}

This study focuses on identifying the challenges of ten higher education teachers in delivering online teaching and learning. There were three-division identified from the findings of the study: digital divide, the teachnology divide, and the communication presence divide.

The first division highlights the notion of the digital divide between the teachers and students during online teaching and learning. The digital divide is commonly defined as a gap between those who have and do not have internet and computer, making it a multifaceted problem (Chang, 2014; Dijk, 2006). Access to quality and equitable internet connectivity uplifts online teaching and learning productivity. However, higher education teachers experience the digital divide. Alvarez (2020) claimed that the digital gap worsened by the pandemic era, which became more of a luxury than a privilege.

Additionally, the launching of policies and initiatives is a challenge among students, teachers, and administrators to meet digital equity (Resta \& Laferrière, 2015; Soomro, Kale, Curtis, Akcaoglu, \& Bernstien, 2020). It should involve other stakeholders to achieve digital equity. The results implied that although Information and Communication Technology (ICT) assist in online teaching to achieve 21st-century skills for students, it is unguaranteed that all have equal access to it and might still trigger other different roadblocks to higher education teachers. Furthermore, several studies also noted the digital divide during emergency remote education (Alvarez, 2021; Khatoony \& Neshadmehr, 2020; Lestiyanawati \& Widyantoro, 2020; Mishra et al., 2020; Rasmatadila, Aliyyah, Rachmadtulla, Samdunin, Syaodih, Nurtanto, \& Tambunan, 2020).

Moreover, the second division, as the term implies in this study, is teachnology. These pertain to the teaching strategies and pedagogy of teachers in integrating technology. One of the roadblocks encountered by the higher education teachers is student engagement with technology integration during emergency remote education.

Student engagement is vital in teaching and learning in traditional instruction. However, this is entirely different from the conventional way of teaching because it requires different approaches. Thus, teachers still struggle to effectively engage and condition the students to participate in activities and discussions, given that this is new in education. The result of the study corroborates with the study of Rasmatadila et al. (2020), wherein the Iranian teachers find it hard to engage the students in an online setup. Furthermore, research findings in the study of Lestiyanawati and Widyantoro (2020) also reflected the teachnology divide in terms of explaining the materials online. Their results were somehow related to the third division, the communication presence divide.

Distant communication between teachers and students was made possible by technology even in when prepandemic era. Given its advantages, it is a reality that distant communication is not always enough to reach the students, especially during emergency remote education. It seems that Covid-19 intensified this communication presence divide. The same results corroborate the study of Alawamleh et al. (2020), wherein they found the negative effects of online learning communication between students and teachers. Additionally, Mayende, Prinz, and Isabw (2017) found that most communication in an online learning system is about technical problems, and only $20 \%$ are active, while $80 \%$ are passive students. Khatoony \& Nedzhamehr (2020) also noted the demotivation of the student during online classes. Findings of the research indicate that communication between the teacher and student should take into consideration for it affects the teaching and learning in an online learning environment. For instance, König et al. (2020) suggested that people should learn to establish communication and interaction differently. These three divisions may set as an eye-opener for other teachers, students, school administrators, and policymakers to take action on the realities of emergency remote education. Those who have the power to contribute to improving the quality of education in the Philippines should not turn a blind eye to these problems. Yet, these divisions may not be stopped but can be prevented and improved.

\section{Conclusion and suggestions}

This study focuses on the roadblocks encountered by ten higher education teachers in migrating conventional modes of instruction. This study also aims to provide series of recommendations to improve the quality of online 
teaching in the time of pandemic crisis and to contribute to the ongoing discussions about emergency remote education. The researchers utilized a qualitative case study research to identify different teacher's roadblocks during quarantine teaching.

Interestingly, three themes or divisions emerged from the study findings: digital, teachnology, and communication presence. This study gave voice to the struggles of higher education teachers in conducting emergency remote education. Furthermore, this evidence-based finding may help contribute to the ongoing discussions about the challenges encountered by teachers and emergency remote education. This study revealed teachers' roadblocks that may serve as an eye opener and basis on how to effectively improve emergency remote education.

Even though online learning already exists in the pre-pandemic era, the same problems such as these divisions still emerge and intensify during this health emergency crisis. Further, the following recommendations should be taken into account (1) government, public, and private educational sectors should collaborate to initiate policies regarding digital inclusion, (2) empirical studies regarding efficient and effective teachnology approaches and effective communication during emergency remote education and post-pandemic should be made, lastly (3) since generalization cannot be made, it is recommended to conduct a study with a larger sample using the same or different approach. These recommendations may help to create an online environment conducive to learning during emergency remote education.

\section{Author contribution statements}

Authors contributed equally to the design and implementation of the research, to the analysis of the results and to the writing of the manuscript.

\section{Disclosure statement}

No potential conflict of interest was reported by the authors.

\section{Ethics committee approval}

All responsibility belongs to the researchers. All parties were involved in the research of their own free will.

\section{References}

Adnan, M., \& Anwar, K. (2020). Online learning amid the COVID-19 pandemic: Students' perspectives. Journal of Pedagogical Sociology and Psychology, 2(1), 45-51. doi:10.33902/JPSP. 2020261309

Alawamleh, M., Al-Twait, L. M., \& Al-Saht, G. R. (2020). The effect of online learning on communication between instructors and students during Covid-19 pandemic. Asian Education and Development. doi:10.1108/AEDS-06-2020-0131

Alea, L. A., Fabrea, M. F., Roldan, R. D., \& Farooqi, A. Z. (2020). Teachers' awareness, distance learning education experiences and perceptions towards institutional readiness and challenges. International Journal of Learning, Teaching and Educational Research, 19(6), 127-144. doi:10.26803/ijlter.19.6.8

Alvarez, J. A. (2021). Rethinking the digital divide in the time of crisis. Globus Journal of Progressive Education, 11(1), 2628. doi: $10.46360 /$ globus.edu. 220211006

Arinto, P. (2016). Issues and challenges in open and distance e-learning: Perspectives from the Philippines. International Review of Research in Open and Distributed Learning, 17(2), 162-180.

Asio, J. M., \& Bayucca, S. A. (2021). Spearheading education during the Covid-19 rife: Administrator's level of digital competence and schools' readiness on distance learning. Journal of Pedagogical Sociology and Psychology, 3(1), 19-26. doi:10.33902/JPSP.2021364728

Basalaia, G., \& Kvavadze, D. (2020). Transition to online education in schools during a SARS-Cov-2 coronavirus (COVID19) pandemic in Georgia. Pedagogical Research, 5(4), 1-9.

Bozkurt, A., \& Sharma, R. C. (2020). Emergency remote teaching in a time of global crisis due to Corona Virus pandemic. Asian Journal of Distance Education, 15(1), i-vi. doi:10.5281/zenodo. 3778083

Bozkurt, A., Jung, I., Xiao, J., Vladimirschi, V., Schuwer, R., Egorov, G., . . Paskevicius, M. (2020). A global outlook to the interruption of education due to COVID-19 pandemic: Navigating in a time of uncertainty and crisis. Asian Journal of Distance Education, 15(1), 1-126. doi:10.5281/zenodo.3878572

Braun, V. \&. (2013). Teaching thematic analysis: Overcoming challenges and developing strategies for effective learning. The Psychologist, 26(2), 120-123. 
Chang, Y. W. (2014). A three-tier ICT access model for intention to participate online a comparison of developed and developing countries. Information Development. doi:10.1177/0266666914529294

Coman, C., Tiru, L. G., Mesesan-Schmitz, L., Stanciu, C., \& Bularca, M. C. (2020). Online teaching and learning in higher education during the coronavirus pandemic: Student's perspective. Sustainability, 12, 1-24. doi:10.3390/su122410367

Danjou, P.-E. (2020). Distance teaching of organic chemistry tutorials during the COVID-19 pandemic: Focus on the use of videos and social media. Journal of Chemical Education, A-D. doi:10.1021/acs.jchemed.0c00485

Dijk, J. A. (2006). Digital divide research, achievements, and shortcomings. Elsevier, 34, 221-235.

Esterberg, K. G. (2002). Qualitative methods in social research. Boston, MA: McGraw-Hill.

Gautam, D. K., \& Gautam, P. K. (2020). Transition to online higher education during COVID-19 pandemic: Turmoil and way forward to developing country of South Asia-Nepal. Journal of Research in Innovative Teaching and Learning, 14(1), 93111. doi:10.1108/JRIT-10-2020-0051

Ho, J., \& Tay, L. Y. (2020). Ensuring learning continues during a pandemic. International Studies in Educational Administration, 48, 49-55.

Hodges, C., Moore, S., Lockee, B., Trust, T., \& Bond, A. (2020, March 27). The difference between emergency remote teaching and online learning. Retrieved from https://er.educause.edu/articles/2020/3/the-difference-between-emergency-remoteteaching-and-online-learning

Hussein, E., Daoud, S., Alrabaiah, H., \& Badawi, R. (2020). Exploring undergraduate student's attitudes towards emergency online learning during Covid-19: A case from the UAE. Children and Youth Services Review, 119, 1-7.

Joaquin, J. J., \& Biana, H. T. (2020). The Philippine Higher Education sector in the time of Covid-19. Frontiers in Education, 5(576371), 2-6. doi:10.3389/feduc.2020.576371

Khatoony, S., \& Nezhadmehr, M. (2020). EFL's teachers' challenges in the integration of technology for online classrooms during Coronavirus (COVID-19) Pandemic in Iran. The Asian Journal of English Language \& Pedagogy, 9 (Special Issue), 1-16. doi:10.37134/ajelp.vol8.sp.1.2020

Koehler, A. A., \& Farmer, T. (2020). Preparing for e learning using digital learning plans. In R.

Ferdig, E. Baumgartner, R. Hartshorne, R. Kaplan-Rokowski, \& C. Mouza, Teaching, Technology, and Teacher Education During the COVID-19 Pandemic: Stories from the Field (pp. 47-51). Association for the Advancement of Computing in Education. Retrieved from https://www.learntechlib.org/p/216903/.

König, J., Jäger-Biela, D. J., \& Glutsch, N. (2020). Adapting to online teaching during COVID-19 school closure: teacher education and teacher competence effects among early career teachers in Germany. European Journal of Teacher Education, 43(4), 608-622. doi:10.1080/02619768.2020.1809650

Kvale, S. (1996). Interviews: An introduction to qualitative research interviewing. Thousand Oaks, CA: Sage.

Lestiyanawati, R., \& Widyantoro, A. (2020). Strategies and problems faced by Indonesian teachers in conducting e-learning system during Covid-19 outbreak. Journal of Culture, Literature, Linguistics and English Teaching, 2(1), 71-82.

Lincoln, Y. S., \& Guba, E. G. (1985). Naturalistic inquiry. Newbury Park, CA: Sage.

Mayende, G., Prinz, A., \& Isabwe, G. M. (2017). Improving communication in online learning system.

Proceedings of the 9th International Conference on Computer Supported Education (CSEDU 2017). 1, pp. 300-207. Science and Technology Publications, Lda. doi:10.5220/0006311103000307

Mishra, L., Gupta, T., \& Shree, A. (2020). Online teaching-learning in higher education during lockdown period of Covid-19 pandemic. International Journal of Educational Research Open. doi:10.1016/j.ijedro.2020.100012

Merriam, S. A. (1998). Conducting effective interview. In case study research in education (1st Ed). San Francisco, CA: JosseyBass.

Merriam, S. B. (2002). Qualitative research in practice: Examples for discussion and analysis. San Francisco, CA: Jossey-Bass.

Mishra, L., Gupta, T., \& Shree, A. (2020). Online teaching-learning in higher education during lockdown period of Covid-19 pandemic. International Journal of Educational Research Open. doi:10.1016/j.ijedro.2020.100012

Naciri, A., Baba, M. A., Achbani, A., \& Kharbach, A. (2020). Mobile learning in higher education: Unavoidable alternative during COVID-19. Aquademia, 4(1), 1-2.

Patton, M. Q. (1987). How to use qualitative methods in evaluation (2nd Ed). Newbury Park, CA: Sage.

Quezada, R. L., Talbot, C., \& Quezada-Parker, K. B. (2020). From bricks and mortar to remote teaching: A teacher education programme's response to COVID-19. Journal of Education for Teaching, 1-12. doi:10.1080/02607476.2020.1801330 
Rasmitadila, Aliyyah, R. R., Rachmadtulla, R., Samdunin, A., Syaodih, E., Nurtanto, M., \& Tambunan, A. R. (2020). The perceptions of primary school teachers of online learning during the Covid-19 pandemic period: A case study in Indonesia. Journal of Ethnic and Cultural Studies, 7(2), 90-109. doi:10.29333/ejecs/388

Resta, P. \&. (2015). Digital equity and intercultural education. Education and Information Technologies, 20(4), 743-756. doi:10.1007/s10639-015-9419-z.

Santi, E. A., Gorghui, G., \& Pribeanu, C. (2020). Teacher's perceived self-efficacy for mobile teaching and learning. Revista Românească pentru Educaţie Multidimensională, 12(1), 157-166. doi:10.18662/rrem/12.1sup2/259

Simamora, R. M. (2020). The challenges of online learning during the Covid-19 pandemic: An essay analysis of performing arts education students. Studies in Learning and Teaching, 1(2), 86-103. doi:10.46627/silet.v1i2.38

Sintema, E. J. (2020). E-learning and smart revision portal for Zambian primary and secondary school learners: A digitalized virtual classroom in the COVID-19 era and beyond. Aquademia, 4(1), 1-2.

Soomro, K. A., Kale, U., Curtis, R., Akcaoglu, M., \& Bernstien, M. (2020). Digital divide among higher education faculty. International Journal of Educational Technology in Higher Education, 17(21), 1-16. doi:10.1186/s41239-020-00191-5

Stake, R. E. (1995). The art of case study research. Thousand Oaks, CA: Sage.

Stake, R. E. (2000). The art of case study research: Perspectives on practice (2nd ed). Thousand Oaks, CA: Sage.

Tejedor, S., Cervi, L., Perez-Escoda, A., Tusa, F., \& Parola, A. (2020). Higher education response in the time of Coronavirus: Perceptions of teachers and students, and open innovation. Journal of Open Innovation, 7(43), 1-15. doi: $10.3390 /$ joitmc 7010043

Tomaro, Q. P., \& Mutiarin, D. (2018). ICT integration in the educational system of Philippines. Journal of Governance and Public Policy, 5(3), 259-282. doi:10.18196/jgpp.5399

Toquero, C. M. (2020). Emergency remote teaching amid COVID-19: The turning point. Asian Journal of Distance Education, 15(1), 185-188. doi:10.5281/zenodo. 3881748

Yanus, A., Abubakar, S., \& Abudu, Z. A. (2020). COVID-19 pandemic lockdown: Online platforms as panacea for effective teaching and learning in Nigerian secondary schools. Journal of Social Sciences and Humanities, 93-102. Retrieved from http://ejournal.ukm.my/ebangi/article/view/41246

Yin, R. K. (2009). Case study research: Design and methods (4th ed.). Thousand Oaks, CA: Sage. 